\title{
The information needs and the information seeking behaviour of a national sample of the population in the United Kingdom, with special reference to needs related to citizenship
}

\section{Rita Marcella and Graeme Baxter}

\begin{abstract}
This paper reports the results of a survey of information needs and information seeking behaviour of a national sample of the UK population. The project was funded by the BLR\&IC and comprised a survey by questionnaire covering all regions of the United Kingdom. 1294 responses were received giving a valid and demographically representative response rate of 45.7\%. Major findings include: that the majority of respondents had sought information in the past (59.4\%) and that an even greater number predicted a future need for information (78.4\%). Over three quarters of respondents said that they would use public libraries and between half and three quarters would approach CABx, post offices, government departments or family and friends. Face to face communications and reading a book were the most popular means of accessing information but a wide variety of other preferred options were cited. Only a small proportion expressed a preference for using a computer to seek information and there was a clear emphasis on public libraries as an appropriate location for accessing computerised information. A highly significant majority $(79.2 \%)$ believed that access to information was very important for exercising their rights as a citizen. Many significant variables, in terms of age, gender, status and region were found. In particular it was felt significant that young people were less sure of the importance of being able to access information.
\end{abstract}

Rita Marcella is Reader/Senior Lecturer at the School of Information and Media, the Robert Gordon University, Aberdeen. She has been the Course Leader for the MSc in Information Analysis since its inception. Research interests include: citizenship information, European information, business information and the management of help desks. She has also published textbooks on classification and biography for children.

Graeme Baxter is a Research Assistant at the School of Information and Media, the Robert Gordon University, Aberdeen. A former student of the School, his research interests include citizenship information and European information.

Keywords: citizenship information; information needs; information seeking behaviour; citizens; general public; surveys; United Kingdom. 


\section{Introduction and background}

This paper reports the results of the first stage of the Citizenship Information research project funded by the British Library Research \& Innovation Centre, a questionnaire-based survey of a sample of the UK population, designed to elicit preliminary data on their use of and need for citizenship information.

In design and execution of the project, the authors drew upon a range of existing research and published literature. The work of Marshall [1], the National Consumer Council [2] and the Policy Studies Institute [3] on the role of information in citizenship and the distinction between the consumer and participant citizen has underpinned the authors' formulation of a definition of citizenship information. There were also links with definitions of community information, such as those of the Library Association [4] and Donohue [5]. Prior research on information needs, as in for example Bruce et al [6] and Tinker et al [7], has also been relevant. The most influential studies have, however, been the 1973 Baltimore survey (Warner et al [8]), and a project carried out in 1977 by the Centre for Research on User Studies at the University of Sheffield [9].

Professional and representative bodies, such as the Library Association [10] and UNESCO [11] and the Public Library Review [12] have argued the importance of public libraries providing citizenship information. Commentators, such as Usherwood [13] and Swash and Marsland [14] and the Comedia report [15] argue that there will be a rise in public expectation of public libraries in terms of citizenship information provision. A current project at the University of Sheffield [16] is seeking to provide qualitative evaluation of the social impact of libraries. There have been some investigations of the provision and use of citizenship/community information in UK public libraries, as in for example White [17] and Toop and Forejt [18].

Government policy in this area has developed rapidly over the last ten years from The Local Government (Access to Information) Act (1986) [19] which gave the public the right to attend council meetings and to gain access to relevant documents. A non-statutory Code of Practice on Access to Government Information [20] was introduced in 1994. In support of the initiative, the UK Government Information Web Server [21] was established. The government's first two reports on the Code $[22,23]$ were positive about its contribution to openness, but there are many, such as Frankel [24] and Raab [25], who have been highly 
critical. The Freedom of Information White Paper [26] should result in a more proactive release of information, and future legislation will impose duties upon public authorities to make certain information publicly available. The Crown Copyright Green Paper [27] posits the possible abolishment of restrictions and the placing of all material originated by government in the public domain.

Government supported IT initiatives have included the plan to introduce government services delivered electronically as detailed in the government.direct Green Paper [28], and the establishment of UK Citizens Online Democracy (UKCOD), which has conducted a number of interesting experiments in electronic democracy [29]. The Parliamentary Office for Science and Technology reported in 1998 upon the potential for electronic interchange of information between government and the electorate [30]. The Coalition for Public Information (CoPI) was established in 1996 with the aim of ensuring that information and communications infrastructures in the UK enable individuals and organisations to participate in 'social, economic and democratic activity' [31]. In the aftermath of the Public Library Review, a Library and Information Commission working party was set up to develop a public library networking plan which resulted in the publication of a report recommending the creation of a network linking public libraries [32]. Despite the rejection of the Information for All bid for Millennium Commission funds, the New Opportunities Fund includes a plan to train some 10,000 library staff in information and communications technology by the year $2001[33]$.

There would appear presently to be a strong body of opinion which suggests that the provision of citizenship information aids the democratic process; however, there has been little basic research testing the validity of the hypothesis.

\section{Methodology}

The aims of the first stage of the project were:

- to gather quantitative and qualitative data on the citizenship information needs and information seeking behaviour of the general public in the United Kingdom

- to analyse the resulting data in order to identify broad patterns emerging and to determine which variables impacted upon response. 
These aims were achieved via a national survey by questionnaire. Prior to its dissemination, the questionnaire was tested on 100 users of Aberdeen City Libraries. A copy of the final version can be found at Appendix I.

The authors have developed the following definition of citizenship information:

Citizenship information is information produced by or about national and local government, government departments and public sector organisations which may be of value to the citizen either as part of everyday life or in the participation by the citizen in government and policy formulation.

However, the questionnaire was designed in order to elicit openly the views of respondents as to the nature of citizenship information rather than impose a preconceived and limited conception: the questionnaire, therefore, did not contain a definition. For the dissemination of the questionnaire (in English and Welsh), the help of public library authorities, Citizens Advice Bureaux and other generalist information and advice agencies was enlisted. In each of the 13 Government Office Regions of the UK one public library authority, plus either one $\mathrm{CAB}$ or other advice agency, were asked to distribute questionnaires to their users/clients. In addition, the public library authorities were asked to distribute half of their allocated questionnaires from a central reference library, and the other half from one of their busier branch libraries. In total, some 2830 questionnaires were disseminated from 42 service points in 28 organisations.

Public libraries were asked to apply systematic sampling, whereby every 10th user approaching the issue/enquiry desk in each distribution point would be given a questionnaire. Given that the number of enquiries received annually by $\mathrm{CABx}$ throughout the $\mathrm{UK}$ is far fewer than that received by public libraries (in 1995-96, 6,956,459 enquiries in CABx [34, 35] compared with $57,327,000$ enquiries in public libraries [36]) the CABx and the other advice agencies were asked if they could hand out questionnaires to every second user. In order to obtain as high a response rate as possible, all organisations were also asked if they could request that the users complete and return the questionnaires at the time of their distribution. Distribution of the questionnaires began on 9th June 1997 and finished on 31st October 1997. The data from the completed questionnaires were analysed using the statistical software package SPSS for Windows; significant statistical relationships between variables (at the $95 \%$ confidence level) were identified using the chi-square test. 
1294 of the 2830 questionnaires were completed and returned, giving a satisfactory response rate of $45.7 \%$.

The response rates for each Government Office Region were relatively even ranging from $42.5 \%$ in the North West to $54.5 \%$ in the North East: only Northern Ireland at $75 \%$ and Wales at $14.7 \%$ fell outwith. There was an overwhelmingly better response from the public libraries as a distribution mechanism (see Table 1). While just under half (49.6\%) of the original questionnaires were distributed by public libraries, over $75 \%$ of the completed survey forms were returned by public libraries. The public library response rate of $69.4 \%$ compares favourably with that of the $\mathrm{CABx}(40.5 \%)$ and the particularly poor response rate of $8.3 \%$ in the other advice and information agencies. This poor response is likely to have resulted from the lack of a central dissemination point for questionnaires, clients' often highly wrought emotional states, and poor literacy levels in some clients.

\begin{tabular}{|l|c|c|c|c|}
\hline \multicolumn{6}{|l|}{ Table 1: Response by type of organisation } \\
\hline Type of Organisation & $\begin{array}{c}\text { Number } \\
\text { distributed }\end{array}$ & $\begin{array}{c}\text { Number } \\
\text { returned }\end{array}$ & $\begin{array}{c}\text { Response } \\
\text { rate (\%) }\end{array}$ & $\begin{array}{c}\text { \% of total } \\
\text { response }\end{array}$ \\
\hline Public library authorities & 1405 & 975 & 69.4 & 75.3 \\
\hline Citizens Advice Bureaux & 625 & 253 & 40.5 & 19.6 \\
\hline Other advice agencies & 800 & 66 & 8.3 & 5.1 \\
\hline Total & $\mathbf{2 8 3 0}$ & $\mathbf{1 2 9 4}$ & & $\mathbf{1 0 0}$ \\
\hline
\end{tabular}

Although fewer than $50 \%$ of the questionnaires were distributed via public libraries, with over $75 \%$ of the completed questionnaires returned from public library respondents, it might initially appear that the survey results would be biased towards the opinions of public library users and not representative of the UK population as a whole. It should be noted, however, that a recent Library and Information Commission report [32] states that libraries are used by a majority (58\%) of the UK public, and that almost a quarter of the present survey's respondents were not public library users. The survey was not designed to reach a precise, stratified sample of the population as a whole: however when the respondents' demographic details were statistically analysed it became clear that the figures were sufficiently close to national averages for generalisations to be drawn and there were no groups in the population that were poorly represented in the sample. However, the results of the survey, in particular in relation to public library services, should be viewed in the light of this high representation of public library users amongst respondents. 


\section{Demographic details of respondents}

The set of responses received reflect a sound representative sample of the constitution of the population of the United Kingdom in terms of the major demographic variables. Of the 1294 completed questionnaires, 190 (14.7\%) were returned from rural areas. The proportion of rural respondents to this survey is close to the national figure, in 1995, of $18.2 \%$ [37, p. 30].

Table 2 indicates the gender and age group of the respondents. In 1995, 49\% of the UK population were males, $51 \%$ were females [38]. The male/female ratio in this survey is, therefore, almost identical to that nationally. Interestingly, in the public libraries, the percentage of male respondents was $48.9 \%$ compared to $50.3 \%$ female; this suggests a far smaller difference in library use by gender than that traditionally expected.

\begin{tabular}{|l|c|c|c|c|}
\hline \multicolumn{6}{|l|}{ Table 2: Gender and age of respondents } \\
\hline & \multicolumn{5}{|c|}{ Gender } \\
\hline Age Group[39] & Male & Female & $\begin{array}{c}\text { Not } \\
\text { specified }\end{array}$ & Totals \\
\hline Under 15 & 10 & 21 & - & $31(2.4 \%)$ \\
\hline $15-19$ & 37 & 61 & 1 & $99(7.7 \%)$ \\
\hline $20-29$ & 126 & 120 & 1 & $247(19.1 \%)$ \\
\hline $30-44$ & 177 & 190 & 1 & $368(28.4 \%)$ \\
\hline $45-54$ & 90 & 111 & - & $201(15.5 \%)$ \\
\hline $55-64$ & 82 & 76 & 1 & $159(12.3 \%)$ \\
\hline $65-74$ & 71 & 54 & 3 & $128(9.9 \%)$ \\
\hline 75 or over & 33 & 16 & 3 & $52(4.0 \%)$ \\
\hline Age not specified & 4 & 4 & 1 & $9(0.7 \%)$ \\
\hline & $\mathbf{6 3 0}$ & $\mathbf{6 5 3}$ & $\mathbf{1 1}$ & $\mathbf{1 2 9 4}(\mathbf{1 0 0 \%})$ \\
\hline & $\mathbf{4 8 . 7 \% )}$ & $\mathbf{( 5 0 . 5 \% )}$ & $\mathbf{( 0 . 9 \% )}$ & \\
\hline
\end{tabular}

In total, $100(7.7 \%)$ of the respondents belonged to an ethnic minority group: in 1996, the Office for National Statistics Labour Force Survey estimated that just under 6\% of the population in Great Britain belonged to an ethnic minority group [37, p. 31].

As Table 3 reveals, $55.5 \%$ of the respondents were economically active and this compares with the national figure, in Spring 1996, of $48.9 \%$ [40 , p. 46]. With regard to the economically inactive respondents in the survey, $14.1 \%$ were students, compared with the national figure, in 1994/95, of $23.1 \%$ [40, p. 56].

Table 3: Status of respondents 


\begin{tabular}{|l|c|c|c|c|}
\hline Status & Male & Female & $\begin{array}{c}\text { Sex not } \\
\text { specified }\end{array}$ & Totals \\
\hline In paid employment & 204 & 242 & - & $\mathbf{4 4 6 ( 3 4 . 5 \% )}$ \\
\hline Self employed & 55 & 37 & 3 & $\mathbf{9 5}(\mathbf{7 . 3 \%})$ \\
\hline Seeking work & 117 & 60 & - & $\mathbf{1 7 7}(\mathbf{1 3 . 7 \%})$ \\
\hline Retired & 160 & 103 & 6 & $\mathbf{2 6 9}(\mathbf{2 0 . 8 \% )}$ \\
\hline Running a home & 9 & 77 & - & $\mathbf{8 6}(\mathbf{6 . 6 \%})$ \\
\hline Student & 66 & 115 & 1 & $\mathbf{1 8 2}(\mathbf{1 4 . 1 \% )}$ \\
\hline Status not specified & 19 & 19 & 1 & $\mathbf{3 9}(\mathbf{3 . 0 \%})$ \\
\hline Totals & 630 & 653 & 11 & $\mathbf{1 2 9 4}(\mathbf{1 0 0 \% )}$ \\
\hline
\end{tabular}

The 541 respondents who were either in paid employment or were self employed were asked to specify their occupation. These were allocated a social class using the Office of Population Censuses and Surveys Standard Occupational Classification [41] (see Table 4). In comparison with the Labour Force Survey, from the Office for National Statistics [40, p. 46], respondents to the survey come to a greater extent proportionally from the professional and managerial categories than for the UK as a whole.

\begin{tabular}{|l|c|c|c|c|}
\hline \multicolumn{7}{|l|}{ Table 4: Social class of employed respondents } \\
\hline Social Class & Male & Female & Totals & $\begin{array}{c}\text { \% } \\
\text { (of 409) }\end{array}$ \\
\hline I $\quad$ Professional, etc. occupations & 29 & 10 & 39 & $\mathbf{9 . 5}$ \\
\hline $\begin{array}{l}\text { II } \\
\text { occupations }\end{array}$ & 80 & 79 & 159 & $\mathbf{3 8 . 9}$ \\
\hline III(N) Skilled occupations non-manual & 31 & 83 & 114 & $\mathbf{2 7 . 9}$ \\
\hline III(M) Skilled occupations manual & 24 & 17 & 41 & $\mathbf{1 0 . 0}$ \\
\hline IV Partly skilled occupations & 24 & 18 & 42 & $\mathbf{1 0 . 3}$ \\
\hline V Unskilled occupations & 7 & 7 & 14 & $\mathbf{3 . 4}$ \\
\hline Totals & $\begin{array}{c}\mathbf{1 9 5} \\
\mathbf{( 4 7 . 7 \% )}\end{array}$ & $\begin{array}{c}\mathbf{2 1 4} \\
\mathbf{5 2 . 3 \%})\end{array}$ & $\mathbf{4 0 9}$ & $\mathbf{1 0 0}$ \\
\hline
\end{tabular}

Respondents were asked if they would describe themselves as disabled, and in all 123 (9.5\%) indicated they were disabled in some way. The most recent (1988) national estimate of numbers of disabled people [42] indicated that around $11 \%$ of the population were disabled.

\section{Citizenship information need in the past}

Question 2 was an open question which asked respondents to give an example of an occasion when they had required to look for information to help them make a decision, solve a problem, or understand something better. In total, 769 (59.4\%) of the respondents gave an 
example. While $35(4.6 \%)$ of these respondents felt that past examples of information need were too many to specify, the remainder indicated a wide range of situations in which a need had arisen (see Table 5).

\begin{tabular}{|l|c|c|}
\hline Table 5: Nature of past information need (top ten responses) \\
\hline $\begin{array}{l}\text { Nature of information need } \\
\text { Education }\end{array}$ & $\begin{array}{c}\text { \% (of 769 } \\
\text { respondents) }\end{array}$ \\
$\quad$ - to assist with coursework/projects (139) & \\
$\quad$ - to choose schools/universities/courses (58) & 197 & 25.6 \\
\hline $\begin{array}{l}\text { Leisure and Recreation } \\
\quad \text { hobbies and pastimes (92) } \\
\quad \text { travel and tourism (38) }\end{array}$ & & \\
\hline Health Care & 130 & 16.9 \\
\hline Welfare Benefits & 89 & 11.6 \\
\hline Legal information & 82 & 10.7 \\
\hline Employment / Job opportunities & 75 & 9.8 \\
\hline Financial matters & 64 & 8.3 \\
\hline Consumer and Credit & 40 & 5.2 \\
\hline Housing & 33 & 4.3 \\
\hline Business information & 33 & 4.3 \\
\hline
\end{tabular}

The respondents who indicated they had looked for information in the past were asked where they had gone to obtain the information (see Table 6).

\begin{tabular}{|l|c|c|}
\hline Table 6: Organisations and people visited to obtain information (top ten responses) \\
\hline Organisations / People & Number & $\begin{array}{c}\text { \% (of 769 } \\
\text { respondents) }\end{array}$ \\
\hline Public libraries & 513 & 66.7 \\
\hline Citizens Advice Bureaux & 136 & 17.7 \\
\hline Academic libraries & 59 & 7.7 \\
\hline Other advice centres & 32 & 4.2 \\
\hline Offices of Government departments and agencies & 30 & 3.9 \\
\hline Professional people (e.g. doctors, solicitors) & 27 & 3.5 \\
\hline Local council offices & 16 & 2.1 \\
\hline Voluntary groups and agencies & 14 & 1.8 \\
\hline Internet & 13 & 1.7 \\
\hline The press & 8 & 1.0 \\
\hline
\end{tabular}

For the great majority (66.7\%) the public library had been their resource, with CABx forming the only other significant source (17.7\%). Interesting trends emerged when examining where the respondents had gone to obtain particular types of information. For example, for the top five topics indicated, public libraries were by far the most popular source for educational information $(84.4 \%)$, leisure and recreation information $(95.5 \%)$ and information on health care $(82.3 \%)$. However, for legal information, only $37.5 \%$ had gone to a public library while 
$50 \%$ had gone to a $\mathrm{CAB}$ or another advice agency; and for information on welfare benefits a mere $5 \%$ had gone to public libraries with $75 \%$ having gone to $\mathrm{CABx}$ and other agencies.

The 769 respondents who indicated they had looked for information in the past were asked how satisfied they were with the information they obtained (see Table 7).

\begin{tabular}{|c|c|c|c|c|c|c|}
\hline \multirow[b]{2}{*}{ Was the information: } & \multicolumn{2}{|c|}{ YES } & \multicolumn{2}{|c|}{ NO } & \multicolumn{2}{|c|}{ No response } \\
\hline & No. & $\%$ & No. & $\%$ & No. & $\%$ \\
\hline Easy to understand? & 618 & 80.4 & 72 & 9.4 & 79 & 10.3 \\
\hline Relevant? & 618 & 80.4 & 30 & 3.9 & 121 & 15.7 \\
\hline Accurate? & 547 & 71.1 & 51 & 6.6 & 171 & 22.2 \\
\hline Up to date? & 470 & 61.1 & 114 & 14.8 & 185 & 24.1 \\
\hline Comprehensive? & 479 & 62.3 & 103 & 13.4 & 187 & 24.3 \\
\hline $\begin{array}{l}\text { In a physical form that was } \\
\text { easy to use? }\end{array}$ & 470 & 61.1 & 85 & 11.1 & 214 & 27.8 \\
\hline
\end{tabular}

Accuracy, currency, comprehensiveness and format of information appear to be difficult qualities for users to judge and higher proportions of respondents held no view on these. Generally respondents were happy with the comprehensibility and the relevance of the information found. These measures of satisfaction were cross-tabulated with details of the types of information respondents had looked for, in order to establish whether users were more or less satisfied/dissatisfied with information on particular topics.

Comprehensibility rated highly across the board, with each type of information being regarded as easily understood by at least $69 \%$ of those respondents who had obtained it. Financial information received the highest rating of all, being described as comprehensible by $92.3 \%$ of the respondents who had obtained such information. The least comprehensible types of information were legal information (described as not easily understood by $15.9 \%$ of respondents who had obtained it), and information to assist with educational coursework (15.8\%). Relevance also rated well overall, and apart from welfare benefits information (at $59.1 \%$ ) all information was described as relevant by at least $70 \%$ of the respondents obtaining it. Business information (92.6\%) and information concerning consumer and credit matters $(89.3 \%)$ received the highest ratings. The highest level of dissatisfaction belonged to legal information, with $11.4 \%$ describing it as irrelevant. 
With regard to accuracy, most types of information fared less well, although were still rated as accurate by between $63 \%$ and $79 \%$ of the relevant respondents. The one exception was business information, which was described as accurate by $92.6 \%$ of its users. Again, legal information was the subject of the most dissatisfaction, being cited as inaccurate by $13.6 \%$ of those who had used it. The levels of satisfaction with the currency of information ranged from $56.6 \%$ for information to help with hobbies and pastimes, to $77.8 \%$ for business information. The types of information regarded as least current were travel and tourism information (described as out of date by $25 \%$ of users) and information to assist educational project work $(24.2 \%)$.

In terms of comprehensiveness, business information was again regarded most favourably, with $88.9 \%$ of its users responding positively. The satisfaction levels for the other types of information ranged from $55.9 \%$ for health care, to $70 \%$ for information to help with school and university coursework. Over $20 \%$ of the users of legal information indicated the information they had obtained was not comprehensive. The physical format of financial information (76.9\%) and travel and tourism information (75\%) received the most positive response, but respondents again appeared dissatisfied with information concerning legal matters: only $43.2 \%$ of its users felt that legal information was in an easy to use format.

Levels of satisfaction were also cross-tabulated with details of the major sources of the information in order to investigate whether the public was more or less satisfied/dissatisfied with information from particular providers. With regard to comprehensibility, the organisations generally rated highly. The main exceptions were government departments: although $52.9 \%$ of users felt their information was comprehensible, $41.2 \%$ felt it was not. Relevance also scored relatively well, ranging from $60.7 \%$ for advice agencies to $88.2 \%$ for academic libraries. Accuracy ratings ranged from $58.8 \%$ for Government departments to $76.5 \%$ for academic libraries. In terms of currency ratings were lower, ranging from $52.9 \%$ for Government departments to $67.9 \%$ for advice agencies. Information from Government departments fared badly in terms of comprehensiveness, with just $41.1 \%$ of users indicating it was comprehensive, and $29.4 \%$ stating it was not. Comprehensiveness ratings for the other organisations ranged from $56.6 \%$ for $\mathrm{CABx}$ to $70.6 \%$ for academic libraries. With regard to the physical format of the information, academic libraries (82.4\%) and public libraries $(69.5 \%)$ received the highest ratings, but again Government departments fared less well: only $35.3 \%$ of their users felt their information was in an easy to use format. 
Respondents who had looked for information in the past were asked if there were any kinds of information which might have helped them, but which they had found difficult to obtain. In all, $308(23.8 \%)$ of these respondents had encountered past difficulties. When asked for details, the majority indicated the types of information that had proved difficult to acquire. There was a wide range of responses, with information on legal issues (7.1\%), education (6.2\%), welfare benefits (5.8\%), health care (5.2\%) and employment (4.5\%) being the most frequently cited. A substantial number of respondents preferred to indicate the reasons why they had been unable to access information. Inadequate or unavailable resources (particularly in public libraries) and official secrecy and restricted access (particularly to national and local government information), were the most prominent factors, both being cited by $6.2 \%$ of the respondents.

In addition to the open question asking for an example of information need, respondents were presented with a list of 23 subjects, from which to indicate those which had been sought in the past. Overall, $1100(85 \%)$ had wanted to find out more about at least one of the subjects listed (see Table 8). 


\begin{tabular}{|l|c|c|}
\hline \multicolumn{4}{|l|}{ Table 8: Types of information sought in the past } \\
\hline Subject & Number & $\%$ \\
\hline 1. Leisure and Recreation & 502 & 38.8 \\
\hline 2. Education & 478 & 36.9 \\
\hline 3. Employment / job opportunities & 433 & 33.5 \\
\hline 4. Transport and Travel & 409 & 31.6 \\
\hline 5. Legal information & 326 & 25.2 \\
\hline 6. Health Care & 305 & 23.6 \\
\hline 7. Social Security Benefits & 284 & 21.9 \\
\hline 8. Information about your local council & 280 & 21.6 \\
\hline 9. Financial matters & 273 & 21.1 \\
\hline 10. Environmental information & 263 & 20.3 \\
\hline 11. Information about politics/ UK Govt. & 260 & 20.1 \\
\hline 12. Taxation & 254 & 19.6 \\
\hline 13. Housing & 252 & 19.5 \\
\hline 14. Family / Personal matters & 231 & 17.9 \\
\hline 15. Technology and Communications & 223 & 17.2 \\
\hline 16. Health and Safety at work & 218 & 16.8 \\
\hline 17. Citizens' rights & 202 & 15.6 \\
\hline 18. Information about the European Union & 176 & 13.6 \\
\hline 19. Equal rights and Discrimination & 154 & 11.9 \\
\hline 20. Business opportunities & 151 & 11.7 \\
\hline 21. Crime and Security & 144 & 11.1 \\
\hline 22. Consumer and Credit & 139 & 10.7 \\
\hline 23. Immigration and Nationality & 89 & 6.9 \\
\hline
\end{tabular}

It can be seen that the top 6 responses to the earlier open question (Table 5) - i.e. information on education, leisure, health care, welfare benefits, legal issues and employment - also occupy 6 of the top 7 places here. The one 'newcomer' is transport and travel information, cited here by $31.6 \%$ of the respondents.

The data from Table 8 were cross-tabulated with the demographic data described above in order to establish whether there were any significant demographic variances in past information need. (Please note that differences between the percentages in responses to particular variables will be described in terms of points)

With regard to gender, there were some significant differences between the sexes. For example, $42.1 \%$ of the female respondents had indicated a past need for educational information, compared with $31.7 \%$ of male respondents - a difference of 10.4 points. There had also been a significant female preference for family/personal information (+9.5 points) and health care information $(+8.9)$. Male respondents, meanwhile, manifested greater need for technology and communications $(+7.0)$ and political information $(+6.2)$. There were also 
significant differences between the past needs of the various age groups, the most obvious being that with several topics (e.g. local government, health care, taxation, financial matters, legal issues) the percentages for those aged 19 or under were decidedly lower than the other age groups.

Examining the respondents' status and social class also revealed some significant differences: for example, welfare benefits information had been needed in the past by $36.7 \%$ of those respondents currently seeking work and by $29.1 \%$ of those who were running a home, but only by $17.5 \%$ of the retired and $16.5 \%$ of the students. Employment information was cited by $51.4 \%$ of jobseekers and $41.4 \%$ of the employed, compared with $7.8 \%$ of the retired respondents. $41 \%$ of those in professional occupations indicated they had required political information in the past, compared with $12.2 \%$ of skilled manual workers and $7.1 \%$ of unskilled workers; similar differences were found in the past need for local government information and information about technology and communications.

Geographic variations were also prevalent. For example, only 9.2\% of East Midlands respondents cited a past need for housing information, compared with $31.1 \%$ of those in the South East; and just $9.1 \%$ of Merseyside respondents had wanted tax information, compared with $38.6 \%$ in Wales. Information on local government (+11.1 points), the environment (+9.8) and technology and communications $(+6.3)$ had been more frequently sought in rural areas.

Amongst those in ethnic minority groups, two topics, not unexpectedly, had proved more popular than with the rest of the sample population: $25 \%$ of the ethnic minority respondents had required immigration and nationality information, compared with just $5.4 \%$ of the rest of the survey population; while the percentage requiring information on equal rights and discrimination (23\%) was more than double that of the white respondents $(11 \%)$. There were also significant differences between the past needs of disabled respondents and those without a disability, the most notable being that $43.1 \%$ of disabled respondents had required information on welfare benefits, compared with $21.6 \%$ of those without a disability. Health care information (+9.5 points) had also been more frequently required by disabled respondents.

Respondents were asked to indicate (from a list of 13 reasons) the reasons why they had wanted citizenship information in the past (see Table 9). 


\begin{tabular}{|l|c|c|}
\hline \multicolumn{3}{|l|}{ Table 9: Past reasons for wanting information } \\
\hline Reasons & Number & $\%$ \\
\hline 1. Educational / study reasons & 632 & 48.8 \\
\hline 2. Work-related reasons & 455 & 35.2 \\
\hline 3. A general interest & 431 & 33.3 \\
\hline 4. Family / personal reasons & 426 & 32.9 \\
\hline 5. Recreational reasons & 365 & 28.2 \\
\hline 6. Job-seeking reasons & 359 & 27.7 \\
\hline 7. Health reasons & 303 & 23.4 \\
\hline 8. Financial reasons & 288 & 22.2 \\
\hline 9. Legal reasons & 251 & 19.4 \\
\hline 10. Business / commercial reasons & 157 & 12.1 \\
\hline $\begin{array}{l}\text { 11. For work with a representative / interest } \\
\text { group }\end{array}$ & 141 & 10.9 \\
\hline 12. For political decision-making & 100 & 7.7 \\
\hline 13. Religious reasons & 85 & 6.6 \\
\hline
\end{tabular}

With regard to gender, three notable differences arose: there was a female preference for seeking information for family reasons $(+9.0)$ and for health reasons $(+6.4)$, but a male preference for business reasons (+7.2). With age groups, meanwhile, there were several variations. For example, educational reasons were cited by $61.5 \%$ of those respondents aged 29 or under, but by just $28.9 \%$ of those aged 55 or over; and work-related reasons were identified by $46 \%$ of those aged $30-54$, but only $17.1 \%$ of those aged 55 and over.

Regional differences were many, and inexplicable. There are no apparent reasons why percentages for educational reasons ranged from 38.5\% in Scotland to 63.6\% in Merseyside; and why satisfying a general interest ranged from $27.1 \%$ in the North West to $46.9 \%$ in the South West. With regard to rural areas, a number of reasons were cited more frequently by rural respondents than by those in other areas: a general interest (+10.3 points), health reasons (+9.6), family reasons $(+7.7)$, financial reasons $(+7.2)$, for work with an interest group (+6.3), and business reasons (+5.5). With ethnicity, only one significant difference was identified: $15 \%$ of the ethnic minority respondents identified religious reasons, compared to $5.9 \%$ of the white respondents. Disabled respondents, meanwhile, cited health reasons more frequently $(+21.8)$ than those without a disability.

\section{Future information need}


Using the same list of 23 subjects described above, respondents were asked if they felt they might want to find out more about any of these topics in the future. Overall, 1014 (78.4\%) of the respondents predicted a future need for information on at least one of the subjects listed.

\begin{tabular}{|l|c|c|}
\hline \multicolumn{4}{|l|}{ Table 10: Predicted future information needs } \\
\hline Subject & Number & $\mathbf{\%}$ \\
\hline 1. Leisure and Recreation & 462 & 35.7 \\
\hline 2. Employment / job opportunities & 418 & 32.3 \\
\hline 3. Legal information & 385 & 29.8 \\
\hline 4. Transport and Travel & 375 & 29.0 \\
\hline 5. Education & 364 & 28.1 \\
\hline 6. Health Care & 334 & 25.8 \\
\hline 7. Information about your local council & 308 & 23.8 \\
\hline 8. Taxation & 306 & 23.6 \\
\hline 9. Financial matters & 304 & 23.5 \\
\hline 10. Information about the European Union & 284 & 21.9 \\
\hline 11. Environmental information & 280 & 21.6 \\
\hline 12. Information about politics/ UK Govt. & 272 & 21.0 \\
\hline 13. Citizens' rights & 266 & 20.6 \\
\hline 14. Social Security Benefits & 260 & 20.1 \\
\hline 15. Technology and Communications & 254 & 19.6 \\
\hline 16. Family / Personal matters & 252 & 19.5 \\
\hline 17. Housing & 249 & 19.2 \\
\hline 18. Business opportunities & 228 & 17.6 \\
\hline 19. Health and Safety at work & 217 & 16.8 \\
\hline 20. Crime and Security & 189 & 14.6 \\
\hline 21. Equal rights and Discrimination & 179 & 13.8 \\
\hline 22. Consumer and Credit & 172 & 13.3 \\
\hline 23. Immigration and Nationality & 112 & 8.7 \\
\hline
\end{tabular}

The top six subjects required in the past (leisure and recreation, education, employment, transport and travel, legal issues, and health care) are still regarded as the six types of information most likely to be required in the future, although in a slightly different order of preference. While there has been a slight increase in the predicted need for legal information $(+4.6$ points) and health care information $(+2.2)$, less interest is anticipated in employment $(-1.2)$, transport (-2.6), leisure (-3.1), and most significantly education (-8.8). Information on consumer issues, and on immigration, although showing a slight predicted increase in use, remain the two least favoured subjects. There is an interestingly significant increased perception of information need about the European Union in the future $(+8.3)$.

Gender variations, in terms of subject, were similar to those for past need, although the numerical differences were not so pronounced. Females again had less interest in technology (-7.8 points) and politics (-5.9), but a greater interest in family/personal information (+6.5), health care $(+6.4)$ and education $(+5.0)$. There was also a significant female preference for 
employment information (+5.7). For those aged 44 and under, predicted need was greater than past need for most subjects on the list; while for those aged 45 and over, predicted future use of the majority of subjects was less than past use. This was most noticeable with the 65 and over age group, where there was a drop in interest in all topics, except politics and EU information. Indeed, of the 23 topics, EU information was the only one for which predicted future need was greater than past need for all age groups. Students, jobseekers, and those respondents running a home displayed an increased interest in the vast majority of the topics; while predicted interest from retired respondents was lower in the vast majority of subjects.

Compared with their urban counterparts, respondents in rural areas displayed a significant future preference for local government information ( +9.1 points) and information on transport and travel (+8.0), but less of an interest in employment (-7.6). Respondents from ethnic minority groups, when compared with white respondents, again displayed a preference for information on immigration $(+21.0)$ and equal rights $(+13.2)$, but also significant preferences for information on housing $(+16.0)$, business opportunities $(+14.4)$ and consumer issues (+7.3). Disabled respondents, meanwhile, when compared with those without a disability, showed a greater interest in welfare benefits $(+16.5)$ and equal rights $(+7.8)$, but a lesser interest in many other topics.

Respondents were also asked to predict the reasons why they might want citizenship information in the future (see Table 11).

\begin{tabular}{|l|c|c|}
\hline \multicolumn{3}{|l|}{ Table 11: Predicted reasons for wanting information } \\
\hline Reasons & Number & $\mathbf{\%}$ \\
\hline 1. Educational / study reasons & 632 & 48.8 \\
\hline 2. Work-related reasons & 455 & 35.2 \\
\hline 3. A general interest & 431 & 33.3 \\
\hline 4. Family / personal reasons & 426 & 32.9 \\
\hline 5. Recreational reasons & 365 & 28.2 \\
\hline 6. Job-seeking reasons & 359 & 27.7 \\
\hline 7. Health reasons & 303 & 23.4 \\
\hline 8. Financial reasons & 288 & 22.2 \\
\hline 9. Legal reasons & 251 & 19.4 \\
\hline 10. Business / commercial reasons & 157 & 12.1 \\
\hline $\begin{array}{l}\text { 11. For work with a representative / interest } \\
\text { group }\end{array}$ & 141 & 10.9 \\
\hline 12. For political decision-making & 100 & 7.7 \\
\hline 13. Religious reasons & 85 & 6.6 \\
\hline
\end{tabular}


The four most popular past reasons for seeking information (educational, work-related, family, and satisfying a general interest) are also regarded as the most likely reasons for requiring information in the future. There was, however, a significant reduction in predicted information seeking for educational reasons; it might be hypothesised that this relates to difficulties in predicting future areas of educational deficiency.

Female respondents again predicted a greater need than males for information for family reasons (+6.4 points), but less of a need for business (-9.5), financial (-8.4), and work-related reasons (-6.4). There was a tendency for educational, work-related, jobseeking, and business reasons to be cited less by older respondents; legal and political decision-making reasons also followed a similar pattern. Family reasons were cited more frequently by those aged 30-54. Percentages for educational need ranged from $54.4 \%$ of students to $19.7 \%$ of the retired; and those for family reasons ranged from $40.7 \%$ of those respondents running a home to $19.7 \%$ of the retired. For each reason the lowest response came from either the retired or those running a home.

Certain reasons were cited more frequently by rural respondents than by those living in other areas: a general interest (+8.0 points), family reasons (+7.6), health reasons (+6.6) and work with an interest group (+5.6). Two significant differences were identified, in terms of ethnicity: $15 \%$ of ethnic minority respondents predicted religious reasons, compared with just $5.6 \%$ of white respondents; while $14 \%$ cited political decision-making, compared with $8.3 \%$ of white respondents. Disabled respondents again predicted health reasons more frequently (+19.0 points) than those without a disability.

\section{Preferred sources of information}

Respondents were given a list of organisations and people and asked to indicate whether they would approach them for information frequently or occasionally. In total, 1209 (93.4\%) of the respondents indicated they would approach at least one of the sources to obtain information (see Table 12). 


\begin{tabular}{|l|c|c|}
\hline \multicolumn{3}{|l|}{ Table 12: Preferred sources of information } \\
\hline Organisations / People & No. & $\%$ \\
\hline 1. Public libraries & 1001 & 77.3 \\
\hline 2. Family and friends & 798 & 61.7 \\
\hline $\begin{array}{l}\text { 3. Offices of Govt. depts. and agencies (e.g. } \\
\text { Inland Revenue, Benefits Agency) }\end{array}$ & 697 & 53.9 \\
\hline 4. Post Offices & 687 & 53.1 \\
\hline 5. Citizens Advice Bureaux & 652 & 50.3 \\
\hline $\begin{array}{l}\text { 6. Professional people (e.g. doctors and } \\
\text { social workers) }\end{array}$ & 634 & 49.0 \\
\hline 7. Local council offices & 551 & 42.5 \\
\hline 8. Academic libraries & 509 & 39.4 \\
\hline 9. Other information and advice centres & 406 & 31.4 \\
\hline 10. MPs & 331 & 25.6 \\
\hline 11. Professional / Trade Associations & 293 & 22.6 \\
\hline 12. Chambers of Commerce & 121 & 9.4 \\
\hline
\end{tabular}

When compared with male respondents, females displayed a significantly greater preference for using family and friends (+11.0 points), professional people $(+10.4)$, advice agencies $(+7.3)$, post offices $(+7.3)$ and $\mathrm{CABx}(+4.9)$. There were also several significant variations in terms of age group. For post offices, public libraries, academic libraries, advice agencies, Chambers of Commerce, professional people, and family and friends, the trend was for interest in using these sources to gradually wane as respondents grew older.

In all regions public libraries were the most frequently cited resource, from $68.8 \%$ of respondents in Yorkshire and the Humber to $93.2 \%$ in Wales. Respondents in rural areas, compared with those in other areas, displayed a significantly greater interest in obtaining information from local council offices $(+17.4$ points), professional people $(+11.0)$, post offices $(+10.0)$ and public libraries (+8.0). The ethnic minority groups in the sample displayed a significant preference for visiting advice agencies (+14.8), academic libraries $(+11.6)$, post offices $(+6.4)$ and Chambers of Commerce $(+6.1)$; although public libraries (77\% of ethnic minority respondents), and family and friends (65\%) remained the two most favoured sources. The resource most frequently cited by disabled respondents was the $\mathrm{CABx}$ network (58.5\%), and, when compared with those without a disability, a significant preference was also shown for contact with MPs (+8.5 points). Disabled respondents felt less inclined to obtain information from public libraries (-22.6), academic libraries (-18.3), family and friends (-15.1) and post offices (-9.3). 


\section{Preferred methods of obtaining information}

From a list of methods of obtaining information, respondents were asked to indicate their favourite three methods in order of preference (see Table 13).

\begin{tabular}{|c|c|}
\hline \multicolumn{2}{|c|}{$\begin{array}{l}\text { Table 13: preferred methods of obtaining information- } \\
\text { ranked by weighted scores }\end{array}$} \\
\hline Method & Points \\
\hline 1. Talking face to face with someone & 1023 \\
\hline 2. Reading a book & 848 \\
\hline $\begin{array}{l}\text { 3. Looking through a collection without } \\
\text { help from the staff }\end{array}$ & 827 \\
\hline 4. Reading a newspaper & 679 \\
\hline 5. Talking by telephone to someone & 518 \\
\hline 6. Listening to the radio & 426 \\
\hline 7. Watching television & 411 \\
\hline 8. Reading a leaflet / pamphlet & 312 \\
\hline 9. Using a computer & 275 \\
\hline 10. Reading a magazine & 232 \\
\hline 11. Writing a letter & 171 \\
\hline
\end{tabular}

The responses demonstrate a continuing emphasis upon traditional means of approach. These data suggest that no single mechanism for enabling access to information should be seen as the ultimate solution to the information needs of the citizen. Rather a complementary range of solutions must be available.

Use of a computer was cited as a preferred method by $40.6 \%$ of those aged 19 and under, and by $22.1 \%$ of those aged $20-29$, but by only $10.6 \%$ of those aged 30 or over. Telephone, television and magazines were also cited by a significantly greater proportion of those aged 19 or under than by those in the other age groups; and there was a slight but noticeable preference amongst more mature respondents for radio, newspapers and looking through a collection. The use of computers was cited by $33 \%$ of students, but just $9.7 \%$ of those running a home and $3.4 \%$ of retired respondents. Conversely, listening to the radio and looking through a collection were cited by decidedly fewer students than by those of other status. Significant differences, in terms of social class, were also present, but no clear patterns emerged: for example, preferences for face-to-face communication ranged from $18.2 \%$ of Class V to $71 \%$ of Class III(M). 
Ethnic minority respondents, compared with their white counterparts, indicated a preference for obtaining information by using a computer (+6.5) and watching television $(+6.0)$, but listening to the radio (-11.6), talking by telephone (-10.1) and reading a book (-6.3) were less popular. Disabled respondents, meanwhile, displayed a greater preference for listening to the radio $(+9.3)$ and face to face communication $(+6.2)$ than those without a disability, but were less disposed to obtain information through reading a book (-13.6) or using a computer (-0.3).

Respondents were asked how often they would use computers to look for information, if public access to computers was made more widely available. 969 (74.9\%) of the respondents indicated they would use computers on at least an occasional basis in at least one of the places listed. The majority (940 respondents, 72.6\%) would use computers in public libraries, $488(37.8 \%)$ would make use of such facilities in post offices, $454(35.1 \%)$ in shopping centres, and $378(29.2 \%)$ in town halls.

In terms of gender, only one significant difference in potential use of computers arose: female respondents displayed a preference for using computers in shopping centres $(+8.1$ points). Given the findings discussed earlier in this paper, it is unsurprising that the main variations reflect a substantially higher interest in using computers among younger respondents and students. Ethnic minority respondents displayed a greater willingness to use computers in all of the locations: shopping centres $(+17.2)$, post offices $(+12.2)$, town halls (+9.5) and public libraries (+5.8). Disabled respondents, meanwhile, were less ready to use computers in libraries (-24.0), shopping centres (-18.3), post offices (-12.2) and town halls (6.5) than those without a disability. 


\section{Perceived importance of information to citizens}

In the final question, respondents were asked if they believed that access to accurate and unbiased information is important for exercising their rights as a citizen. Their responses are summarised at Table 14. A highly significant majority (79.2\%) believe that access to high quality information is very important for exercising their rights as citizens.

\begin{tabular}{|l|r|r|}
\hline \multicolumn{3}{|c|}{ Table 14: Importance of information } \\
\hline & Number & \% \\
\hline Very important & 1025 & 79.2 \\
\hline Quite important & 196 & 15.1 \\
\hline Not important & 10 & 0.8 \\
\hline Don't know & 19 & 1.5 \\
\hline No response & 44 & 3.4 \\
\hline Totals & $\mathbf{1 2 9 4}$ & $\mathbf{1 0 0}$ \\
\hline
\end{tabular}

Only three variables were found to be significant from cross tabulations. These reveal that respondents aged under 19 (-20.0 points), students (-10.0) and ethnic minorities (-7.2) were markedly less certain that information was important to them in exercising their rights as citizens.

\section{Conclusions}

It is felt that the survey response (1294) and its demographic composition are sufficiently representative of the UK population as a whole for generalisations to be drawn. The majority of respondents $(59.4 \%)$ had sought information in the past, while just under a quarter (23.8\%) had experienced difficulties in accessing information. Legal information had created significant difficulties in terms of access and use, while respondents cited least satisfaction with information gained from government departments.

Information need related to a range of categories reflecting the significant areas of citizens' experience. Leisure and recreation, education, employment, transport and travel, legal issues, and health care were consistently the most frequently cited for past and future need, although some interesting variation was observed. Educational reasons for information seeking were the most frequently cited both in the past and the predicted future. However, other reasons, such as work-related and a general interest, were significant. 
Over three quarters (77.3\%) of respondents said they would use public libraries on at least an occasional basis. Between $50 \%$ and $75 \%$ of respondents would approach Citizens Advice Bureaux, post offices, Government departments and agencies, or their family and friends. Face to face communications were preferred by the largest number of respondents: however, the traditional book retained its appeal with the second highest number of citations. Other preferred options included browsing in a collection and by telephone. The media, too, were popular, with newspapers being more frequently cited than TV or radio. Only a small proportion of respondents expressed a preference for using a computer to seek information at present, but the majority (74.9\%) indicated that they would use computers if these were more widely available. These data suggest that no single mechanism for enabling access to information should be seen as the ultimate solution to the information needs of the citizen. Rather a complementary range of solutions must be offered.

There was a clear emphasis on public libraries as an appropriate location for computerised access to information for a significant majority (72.6\%) of respondents. However, results suggest that other public places, such as post offices, shopping centres and town halls, would attract a significant body and proportion of the general public.

A highly significant majority (79.2\%) of the respondents believe that access to accurate and unbiased information is very important for exercising their rights as citizens.

Disabled respondents demonstrated an increased need for information on welfare benefits. They cited health reasons for seeking information more frequently and had a greater predicted future interest in welfare benefits and equal rights information, but a lesser past and predicted future interest in most other topics. The agency most frequently cited by disabled respondents was the $\mathrm{CAB}(58.5 \%)$. They displayed a greater preference for accessing information via listening to the radio and face to face communication, but were less ready to use computers in libraries, shopping centres, post offices and town halls.

Interestingly, in the public libraries, the percentage of male respondents was $48.9 \%$ compared to $50.3 \%$ female, suggesting a far smaller difference in library use by gender than that traditionally expected. Results showed a significant female preference for educational, family/personal and health care information. Male respondents, meanwhile, displayed more interest in technology and communications and political information. Female respondents more frequently sought information for family and personal reasons and for health reasons, male respondents for business and commercial reasons. 
Younger respondents showed an increased predicted future use for all topics except education and environmental information: for those aged 45 and over, predicted future use of the majority of subjects was less than past use. Family and personal reasons were cited more frequently by those aged 30-54. Using a computer was cited as a preferred access method by $40.6 \%$ of those aged 19 and under, and by $22.1 \%$ of those aged $20-29$, but by just $10.6 \%$ of those aged 30 or over. Telephone, television and magazines were also cited by a significantly greater proportion of those aged 19 or under; and there was a slight but noticeable preference amongst more mature respondents for radio, newspapers and looking through a collection. However, a highly significant $67.3 \%$ of those aged 55-64, and $40.6 \%$ of those aged 65 and over, indicated a willingness to use computers in public libraries.

Highly significantly those aged 19 or under felt less certain of the importance of information than the other age groups.

The proportion of jobseekers in the CABx (22.5\%) and the other advice agencies $(21.2 \%)$ was effectively twice that in the public libraries (10.9\%). Welfare benefits information had been needed in the past by $36.7 \%$ of those respondents currently seeking work and by $29.1 \%$ of those who were running a home, but only by $17.5 \%$ of the retired and $16.5 \%$ of the students. Employment information was cited by $51.4 \%$ of jobseekers and $41.4 \%$ of the employed, compared with $7.8 \%$ of the retired respondents. Students, jobseekers, and those respondents running a home displayed an increased interest, compared to past need, in the vast majority of the topics; while predicted interest from retired respondents was lower in the vast majority of subjects.

Public libraries, family and friends, academic libraries, post offices, advice agencies and Chambers of Commerce would be approached most frequently by students; $\mathrm{CABx}$, Government departments and MPs would be visited most frequently by jobseekers; employed people would be the most likely users of professional associations; while the most frequent visitors to professional people would be those respondents running a home.

The use of computers was cited by $33 \%$ of students, but just $9.7 \%$ of those running a home and $3.4 \%$ of retired respondents. Conversely, listening to the radio and looking through a collection were cited by decidedly fewer students than by those of other status. Significantly only $69.2 \%$ of the students felt that information access was very important, compared with 
$84.9 \%$ of those running a home, $81.9 \%$ of the employed, $81.4 \%$ of the jobseekers, and $78.8 \%$ of the retired. This reinforces the finding above in relation to young people.

Regional differences were many, highly significant and require further exploration. For example, belief that information was very important ranged from $90.6 \%$ in the South East to $67 \%$ in Yorkshire and the Humber. In all regions public libraries were the most frequently cited resource, from $68.8 \%$ of respondents in Yorkshire and the Humber to $93.2 \%$ in Wales. Respondents in rural areas displayed a significant future preference for local government information and information on transport and travel. They preferred obtaining information from local council offices, professional people, post offices and public libraries. They also tended to obtain information by reading a book, but were less inclined to read a newspaper or use a computer.

Respondents from ethnic minority groups displayed a greater need for information on immigration and equal rights, but also indicated significant preferences for information on housing, business opportunities, and consumer and credit issues. They also preferred to visit advice agencies, academic libraries, post offices and Chambers of Commerce; although public libraries and family and friends remained the two most favoured sources. They indicated a preference for obtaining information by using a computer and watching television. 
Many people need information to help them make decisions or solve problems. As part of a project funded by the British Library, the Robert Gordon University in Aberdeen is currently investigating the information needs of the British public. It would be appreciated if you could spare a few moments to answer the following questions. All completed questionnaires will be treated as strictly anonymous.

[1] Please provide some details about yourself:

(a) Are you: Male $\square \quad$ Female

(b) Are you: Under 15 years of age

15-19

20-29

$30-44$

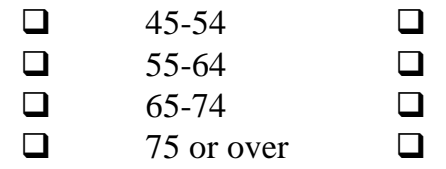

(c) Are you:

White

Black Caribbean

Black African

Black Other

Indian

$\begin{array}{lll}\square & \text { Pakistani } & \square \\ \square & \text { Bangladeshi } & \square \\ \square & \text { Chinese } & \square \\ \square & \text { Other (please specify) } & \square \\ \square & & \end{array}$

(d) Are you:

In paid employment

$\begin{array}{ll}\square & \text { Retired } \\ \square & \text { Running a home } \\ \square & \text { Student }\end{array}$

Self employed

Seeking work

Student

If in paid employment or self employed, please specify your occupation:-

(e) Would you describe yourself as a disabled person?

YES $\square$ NO

[2] Please give an example of an occasion in which you have been required to look for information to help you make a decision, solve a problem, or understand something a little better. This might have been related to health, education, welfare benefits, legal rights, etc. (If you cannot think of an example, please go directly to Question 6)

[3] Where did you go to obtain this information? (Please provide details) 
[4] How satisfied were you with the information you obtained? (Please respond for each of the following). Was it:

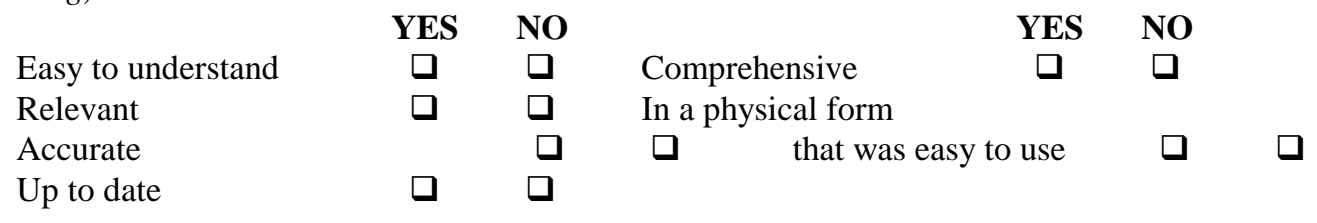

[5] Were there any kinds of information which might have helped you, but which you found difficult to obtain?

\section{YES $\square$ NO}

If YES, please provide details of the kinds of information you found difficult to obtain:

[6] Which of the following subjects have you ever wanted to find out more about in the past, or feel you might want to find out more about in the future? (Please tick all relevant boxes)

\begin{tabular}{|c|c|c|}
\hline & In the past & In the future \\
\hline Information about politics / the UK Government & 口 & 口 \\
\hline Information about your local council & $\square$ & $\square$ \\
\hline Information about the European Union & $\square$ & $\square$ \\
\hline Employment / job opportunities & 口 & $\square$ \\
\hline Health and Safety at work & $\square$ & $\square$ \\
\hline Education & a & 口 \\
\hline Housing & $\square$ & $\square$ \\
\hline Health Care & a & 口 \\
\hline Social Security Benefits & 口 & $\square$ \\
\hline Family / Personal matters & $\square$ & $\square$ \\
\hline Taxation & 口 & 口 \\
\hline Financial matters & $\square$ & $\square$ \\
\hline Consumer and Credit & 口 & 口 \\
\hline Business opportunities & $\square$ & $\square$ \\
\hline Legal information & & \\
\hline Equal rights and Discrimination & 口 & $\square$ \\
\hline Immigration and Nationality & $\square$ & $\square$ \\
\hline Citizens' rights & 口 & $\square$ \\
\hline Crime and Security & $\square$ & $\square$ \\
\hline Transport and Travel & a & 口 \\
\hline Technology and Communications & $\square$ & $\square$ \\
\hline Environmental information & 口 & 口 \\
\hline Leisure and Recreation & 口 & $\square$ \\
\hline Other (please specify) & & \\
\hline
\end{tabular}


[7] For what reasons have you wanted this information in the past, and for what reasons do you think you might want this information in the future? (Please tick all relevant boxes)

\begin{tabular}{|c|c|c|}
\hline & In the past & In the future \\
\hline Educational / study reasons & $\square$ & $\square$ \\
\hline Work-related reasons & 口 & 口 \\
\hline Job-seeking reasons & a & 口 \\
\hline Business / commercial reasons & 口 & 口 \\
\hline Family / personal reasons & 口 & 口 \\
\hline Health reasons & 口 & 口 \\
\hline Financial reasons & 口 & 口 \\
\hline Legal reasons & 口 & 口 \\
\hline Religious reasons & 口 & 口 \\
\hline Recreational reasons & 口 & 口 \\
\hline For political decision-making & a & 口 \\
\hline For work with a representative / interest group & 口 & 口 \\
\hline A general interest & 口 & $\square$ \\
\hline Other (please specify) & & \\
\hline
\end{tabular}

[8] For the following list of organisations and people, please indicate if you would approach them for information frequently or occasionally. (If you do not tick either of the 'frequently' or 'occasionally' options, it will be assumed that you would never approach these organisations or people for information)

Offices of Government departments and agencies

Frequently Occasionally MPs (e.g. Inland Revenue, Benefits Agency)

Local council offices

Post Offices

Public libraries

Academic libraries

Citizens Advice Bureaux

Other information and advice centres

Chambers of Commerce

Professional / Trade Associations

Professional people (e.g. doctors or social workers)

Family and friends

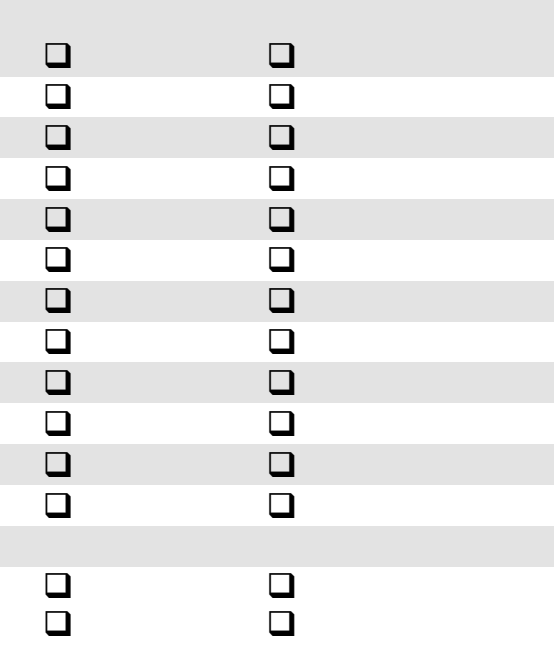

[9] In which language do you prefer to obtain information? (Please tick one box only)

$\begin{array}{llll}\text { English } & \square & \text { Hindi } & \square \\ \text { Welsh } & \square & \text { Punjabi } & \square \\ \text { Scottish Gaelic } & \square & \text { Urdu } & \square \\ \text { Irish } & \square & \text { Chinese } & \square \\ \text { Bengali } & \square & \text { Vietnamese } & \square \\ \text { Gujarati } & \square & \text { Greek } & \square\end{array}$

Turkish

Arabic

Other (please specify) 
[10] From the following, please indicate your favourite three methods of obtaining information. (In the boxes provided, please write a 1 alongside your favourite method, a 2 alongside your 2 nd favourite method, and a 3 alongside your 3rd favourite method)

\begin{tabular}{|l|l|l|l|}
\hline Listening to the radio & Talking by telephone to someone & \\
\hline $\begin{array}{l}\text { Looking through a collection (e.g. in } \\
\text { a library, Citizens Advice Bureau, or } \\
\text { other information centre) without } \\
\text { help from the staff }\end{array}$ & Talking face to face with someone & \\
\hline Reading a book & & $\begin{array}{l}\text { Using a computer (e.g. sending e- } \\
\text { mail, searching the Internet) }\end{array}$ & \\
\hline Reading a leaflet / pamphlet & Watching television & \\
\hline Reading a magazine & Writing a letter & \\
\hline Reading a newspaper & Other (please specify) & \\
\hline
\end{tabular}

[11] If public access to computers was made more widely available to the general public, how often would you use these computers to look for information? (If you do not tick either of the 'frequently' or 'occasionally' options it will be assumed that you would not use these computers)

Computers in public libraries

Computers in post offices

\section{Frequently Occasionally}

Computers in shopping centres

Computers in town halls

Computers in other public places (please specify)

$\begin{array}{ll}\square & \square \\ \square & \square \\ \square & \square \\ \square & \square \\ \square & \square\end{array}$

[12] Do you believe that access to accurate and unbiased information is important for exercising your rights as a citizen? (Please tick one of the following)

Very Important $\quad$ a Quite Important $\quad \begin{array}{llll}\text { Not Important } & \square & \text { Don't Know }\end{array}$

[13] Have you ever been unable to access information which you needed in order to make a decision, solve a problem, or understand something a little better?

YES $\square$ NO

If YES, please briefly describe the circumstances: 


\section{References}

1. MARSHALL, T.H. Citizenship and social class. Cambridge: Cambridge University Press, 1950.

2. NATIONAL CONSUMER COUNCIL. The fourth right of citizenship: a review of local advice centres. London: National Consumer Council, 1977.

3. POLICY STUDIES INSTITUTE. Information and citizenship in the United Kingdom. Draft report prepared as part of the European Commission's Information and citizenship in Europe study. London: Policy Studies Institute, 1995.

4. LIBRARY ASSOCIATION. Community information: what libraries can do. London: Library Association, 1980.

5. DONOHUE, J. C. Community information services - a proposed definition. In: Martin, S.K., ed. Community information politics. Proceedings 39th ASIS annual meeting. Vol. 13. Washington: American Society for Information Science, 1976.

6. BRUCE, I., MCKENNEL, A., AND WALKER, E. Blind and partially sighted adults in Britain: the RNIB survey. London: RNIB, 1991.

7. TINKER, A., MCCREADIE, C., AND SALVAGE, A. The information needs of elderly people: an exploratory study. London: Age Concern Institute of Gerontology, 1993

8. WARNER, E.S., MURRAY, A.D., AND PALMOUR, V.E. Information needs of urban residents. Washington, DC: US Department of Health, Education and Welfare, Office of Education, Bureau of Libraries and Learning Resources, 1973.

9. BEAL, C. Studying the public's information needs. Journal of Librarianship, 11(2), 1979, 130-151.

10. LIBRARY ASSOCIATION. Library Manifesto. London: LA, 1997.

11. UNESCO. Public Library Manifesto 1994.

Available at http://www.unesco.org:80/cii/libmanif/libraman.htm [Accessed March 1997]

12. LIBRARY AND INFORMATION COMMISSION. Review of the public library service in England and Wales for the Department of National Heritage: final report. London: Aslib, 1995.

13. USHERWOOD, R. The public library as public knowledge. London: Library Association, 1989.

14. SWASH, G. AND MARSLAND, G. Current trends in the use of the public library information centre. Library Management, 15 (6), 1994, 20-22.

15. COMEDIA. Borrowed time? The future of public libraries in the UK. Bournes Green: Comedia, 1993.

16. PROCTOR, R., USHERWOOD, R. AND SOBCZYK, G. What happens when a public library service closes down? Library Management, 18 (1\&2), 1997, 59-64.

17. WHITE, D. The provision of community information: what does the public want? CRUS News, 28, 1987, 7-9.

18. TOOP, S., AND FOREJT, M. Provision of community information in public libraries. Library Management, 14 (5), 1993, 16-17.

19. GREAT BRITAIN: HOUSE OF COMMONS. Local Government (Access to Information) Act 1985. London: HMSO, 1985.

20. GREAT BRITAIN: HOUSE OF COMMONS. Code of practice on access to government information. London: HMSO, 1994.

21. Government Information Service. Available at http://www.open.gov.uk [Accessed February 1998]

22. GREAT BRITAIN: HOUSE OF COMMONS. Code of practice on access to government information. London: HMSO, 1994.

23. GREAT BRITAIN: HOUSE OF COMMONS. Code of practice on access to government information: 1995 report. London: HMSO, 1995. 
24. FRANKEL, M. Still no right to know. Assignation, 11 (2), January 1994, 8-10.

25. RAAB, C. D. Open government: policy information and information policy. Political Quarterly, 65(3), July-September 1994, 340-7.

26. GREAT BRITAIN: HOUSE OF COMMONS. Your right to know: the Government's proposals for a Freedom of Information Act. London: The Stationery Office, 1997. (Cm 3818)

27. GREAT BRITAIN: HOUSE OF COMMONS. Crown copyright in the information age: a consultation document on access to public sector information. London: The Stationery Office, 1998. (Cm 3819).

28. government.direct: a prospectus for the electronic delivery of government services. Available at: http://www.open.gov.uk/citu/gdirect/ [Accessed March 1997]

29. UKCOD. Home page. Available at: http://www.democracy.org/uk/ [Accessed February 1998]

30. PARLIAMENTARY OFFICE OF SCIENCE AND TECHNOLOGY. Electronic government: information technologies and the citizen. London: Parliamentary Office of Science and Technology, 1998.

31 COALITION FOR PUBLIC INFORMATION. Home page. Available at: http://www.lahq.org.uk/copi.htm [Accessed January 1998]

32. LIBRARY AND INFORMATION COMMISSION. New library: the people's network. London: LIC, 1997.

33. GREAT BRITAIN: DEPARTMENT FOR CULTURE, MEDIA AND SPORT. The people's lottery: presented to Parliament by the Secretary of State for Culture, Media and Sport by Command of Her Majesty, July 1997. Available at:

http://www.culture.gov.uk/WHITEPAP.HTM [Accessed July 1997]

34. NATIONAL ASSOCIATION OF CITIZENS ADVICE BUREAUX. Delivering human rights: annual report 1995/96. London: NACAB, 1996.

35. CITIZENS ADVICE SCOTLAND. A Scottish voice: annual report 1995/1996.

Edinburgh: Citizens Advice Scotland, 1996.

36. LIBRARY AND INFORMATION STATISTICS UNIT. Library and information

statistics tables 1997. Loughborough: LISU, 1997. Available at

http://info.lut.ac.uk/departments/dils/lisu/publib.html [Accessed January 1998]

37. OFFICE FOR NATIONAL STATISTICS. Social Trends, 1997 edition. London: The

Stationery Office, 1997.

38. OFFICE FOR NATIONAL STATISTICS. Annual Abstract of Statistics, 1997 edition.

London: The Stationery Office, 1997.

39. The age group variables are those used in the Chartered Institute of Public Finance and Accountancy (CIPFA) standard for Public Library User Surveys (PLUS). In: FUEGI, D.

Towards a national standard for a public library user survey. Public Library Journal, 9(2), March/April 1994, 49-51.

40. OFFICE FOR NATIONAL STATISTICS. Regional Trends, 1997 edition. London: The Stationery Office, 1997.

41. OFFICE OF POPULATION CENSUSES AND SURVEYS. Standard Occupational Classification. London: HMSO, 1990 (vols 1 \& 2), 1991 (vol 3).

42. OFFICE OF POPULATION CENSUSES AND SURVEYS. The prevalence of disability among adults: OPCS surveys of disability in Great Britain, Report 1. London: HMSO, 1988. 